\title{
PHYTOCHEMICAL AND ANTIMICROBIAL ANALYSES OF LEAF EXTRACTS OF CERATHOTECA SESAMOIDES AND CHROMOLAENA ODORATA
}

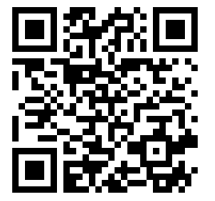

\author{
Abubakar M. A. ${ }^{1}$, Etonihu A. C. ${ }^{*}{ }^{\natural}$, Kigbu P. E. ${ }^{2}$, Owuna J. E. ${ }^{3}$, Audu S. I. 1 \\ ${ }^{1}$ Department of Chemistry, Nasarawa State University, P.M.B 1022, Keffi, Nigeria. \\ 2 Department of Environmental Sciences, Kaduna Polytechnic, Kaduna, Nigeria. \\ ${ }^{3}$ Department of Microbiology, Nasarawa State University, P.M.B 1022, Keffi, Nigeria
}

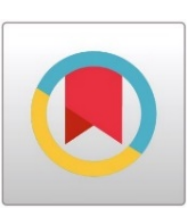

DOI: https://doi.org/10.29121/granthaalayah.v8.i8.2020.435

Article Type: Research Article

Article Citation: Abubakar M. A., Etonihu A. C., Kigbu P. E., Owuna J. E., and Audu S. I.. (2020).

PHYTOCHEMICAL AND

ANTIMICROBIAL ANALYSES OF

LEAF EXTRACTS OF CERATHOTECA SESAMOIDES AND CHROMOLAENA ODORATA. International Journal of Research -GRANTHAALAYAH, 8(8), 65-74.

https://doi.org/10.29121/granthaa layah.v8.i8.2020.435

Received Date: 06 June 2020

Accepted Date: 21 August 2020

Keywords:

Antimicrobial

Leaf Extracts

Medicinal Plants

Nigeria

\section{ABSTRACT}

It was reported in 2005 during WHO survey that about $70-80 \%$ of the world population use medicinal plants either in their crude unmodified form or partially in their modified semi-synthetic form of plant sources in their primary healthcare. The present study investigated the phytochemicals and antimicrobial activities of the leaf extracts of Cerathoteca sesamoides and Chromolaena odorata to ascertain their potentials in herbal medicine. Fresh leaf of the plants obtained from Lafia in Nasarawa State, Nigeria were dried, powdered, and subjected to methanolic extraction, partition, phytochemical, and antimicrobial analyses using standard methods. Partitions from n-hexane, methanol, ethyl acetate, chloroform, and residue extracts were tested against clinical bacteria Escherichia coli, Klebsiella spp., Pseudomonas aeruginosa, Staphylococcus aureus, and fungus Candida albicans. Among the four different solvents used in partitioning methanolic and ethyl acetate extracts of both plants contain flavonoids, tannins, alkaloids, terpenoids, saponins, steroids, and cardiac glycosides. Saponins were absent in the nhexane and chloroform extracts of $\mathrm{C}$. odorata and the ethyl acetate extract of $\mathrm{C}$. sesamoides. While flavonoids were present in the n-hexane extracts of C. odorata, they were absent in C. sesamoides. Anthraquinone and reducing sugar were absent in all the solvent extracts of both medicinal plants. The antimicrobial susceptibility tests showed that n-hexane and residue extracts of both plants had no activity against the tested microorganisms. The chloroform and ethyl acetate extracts of C. sesamoides and C. odorata (at $12.5 \mathrm{mg} / \mathrm{ml}$ ) were active against all the tested clinical bacteria K. spp., E. coli, P. aeruginosa, S. aureus, and C. albicans. The methanolic extracts of both plants were active against the bacterial isolates but inactive against $\mathrm{C}$. albicans. The minimum bactericidal concentration of these plant extracts was $\geq 50 \mathrm{mg}$, while the minimum inhibition concentrations ranged between $12.5 \mathrm{mg}$ and $\geq 50 \mathrm{mg}$. The findings showed that the chloroform or ethyl acetate extracts of the leaves of these plant drugs could be used to treat urinary tract infections. 


\section{INTRODUCTION}

In the last century, roughly 121 pharmaceutical products were formulated based on the traditional knowledge obtained from difference sources (Mukeshwar et al., 2011). Today, it has been developed as a separate industry as many people prefer herbal medicines to synthetic ones. Over 80,000 species of different plants are in use throughout the world, but more than 500 traditional communities use about 800 species of plants for curing different diseases (Kamboj, 2000). WHO survey in 2005 also reported that about 70-80\% of the world population, particularly in the developing countries, depend on non-conventional medicines mainly of plant sources in their primary healthcare. Therefore, WHO has described traditional medicine as one of the surest means to achieve total healthcare coverage of the world's population. In Nigeria, variations can be observed in ethnic names and use of local biodiversity indicating the intimate and independent usages of local resources (Stella et al., 2000). These local resources include the use of plants for treatment of diseases, livestock fodder, human food and nutrition, construction and firewood. Plants used in the treatment of diseases contain active compounds which are phytochemicals with biological activities. Some of which are responsible for the characteristic odours, pungencies and colours of plants while others give a particular plant its culinary, medicinal or poisonous virtues (Evans and Trease, 2002).

Plants are important sources of medicines and presently about $25 \%$ of pharmaceutical prescriptions in Nigeria contain at least one plant-derived ingredient. Various traditional medicine practices have been developed in different cultures, different regions, but without a parallel development of international standards and appropriate ways for evaluating them (WHO, 2005). WHO has encouraged the rational use of plant based medicines by member states and has developed technical guidelines for the assessment of herbal medicines (WHO, 2000).

Ceratotheca sesamoides, a member of the Pedaliaceae family, is a flowering plant of the genus Ceratotheca. It is indigenous to Africa and grows both as a wild weed and locally cultivated species, and is colloquially referred to as false sesame owing to its marked similarities with common sesame (Sesamum indicum). Ceratotheca sesamoides is a plant with many practical uses and applications in food and medicine (Toyin et al., 2012; Adesiyun and Uddin, 2011; Bedigian and Adetula, 2004; Fasakin, 2004). The leaves and flowers are often consumed as vegetables or used in sauces. The leaves also have medicinal benefits while the seeds can produce cooking oil. Aqueous leaf extracts are used in the treatment of diarrhea, dysentery, and measles. The leaf may be an effective anti-oxidant, antiinflammatory and anti-hypertensive agent, while the mucilage can be used as an emollient and lubricant. The slimy liquid produced by soaking the leaves in water can be used to treat conjunctivitis (Adesiyun and Uddin, 2011). Warm leaves can be ground and mixed with ash then applied to inflamed cervical lymph nodes to help expedite delivery in both humans and animals. If the leaves are ground with the rhizome of Anchomanes difformis, the ensuing mixture has been used to treat cases of leprosy. False sesame has been claimed to possess some anti-viral properties and has been employed as an aphrodisiac against jaundice, snakebites and skin diseases (Bedigian and Adetula, 2004). The seed oil is similar in composition to sesame oil and contains sesamin, a phenyl propanoid lignin. This compound showed anti-oxidant, anti-inflammatory, anti-hypertensive, cytotoxic (including anti-tumour) and insecticidal activities (Phan et al., 2001).

Chromolaena odorata, a known toxic weed from the family of Asteraceae, is widespread over many parts of the world, including Nigeria. The weed is known with many common names including "Awolowo", in Igbo language, "Obirato" in Bumaji-Boki, siam weed, bitter bush or jack in the bush (Okon and Amalu, 2003). Chromolaena odorata is also called Independence leaf, as its popularity coincided with Nigeria's Independence in 1960. In traditional medicine, it is used as an anti-spasmodic, anti-protozoal, anti-trypanosomal, anti-bacterial, anti-fungal, antihypertensive, anti- inflammatory, astringent, diuretic and hepatotropic agent (Phan et al., 2001). In Ivory Coast, the plant is exploited for its anti-inflammatory properties, which may be due to the terpenes present, which show excellent inhibition of soya lipoxygenase L-1 (Owoyele et al., 2005; Bedi et al., 2004; Bamba et al., 1993). Other uses include the treatment of abdominal and cervical pain, and of wounds as a local anti-septic agent (Bedi et al., 2004; Bamba et al., 1993). The ethanolic extract is used as an anti-fungal (Ngono et al., 2006). The plant decoction is taken as a remedy for coughs and colds or in baths to treat skin diseases (Morton, 1981), also used in traditional medicine for wound healing and a local anti-septic agent (Inya-Agha et al., 1987). The essential oil from Chromolaena odorata has been reported to exhibit insecticidal and antibacterial activities (Bouda et al., 2001). Despite their many uses and growing domestication at a local level, Ceratotheca sesamoides and Chromolaena odorata plants have remained predominantly underused and undervalued (Falusi et al., 2002). 
This present study investigated the extraction, partition, identification of the bioactive phytoconstituents, and determination of biological activities of the leaf extracts of Ceratotheca sesamoides and Chromolaena odorata against microorganisms.

\section{MATERIALS AND METHODS}

\subsection{COLLECTION AND IDENTIFICATION OF PLANT SAMPLES}

The fresh leaves of Ceratotheca sesamoides (Plate 1) and Chromolaena odorata (Plate 2) were collected from the wild at Government Residential Area and Bukan Ari in Lafia Local Government Area of Nasarawa State in Nigeria. The plant leaves were identified and authenticated by Prof. A.O. Ogaraku of the Department of Plant Science and Biotechnology of Nasarawa State University, Keffi.

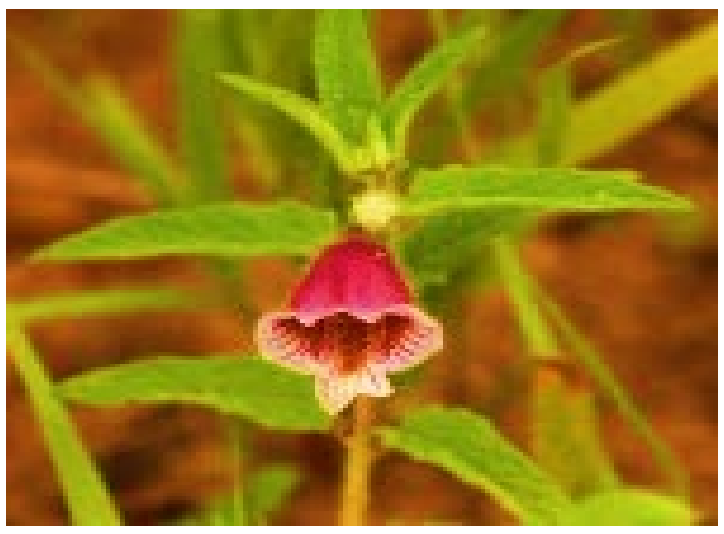

Plate 1: Leaves and flower of C. sesamoides

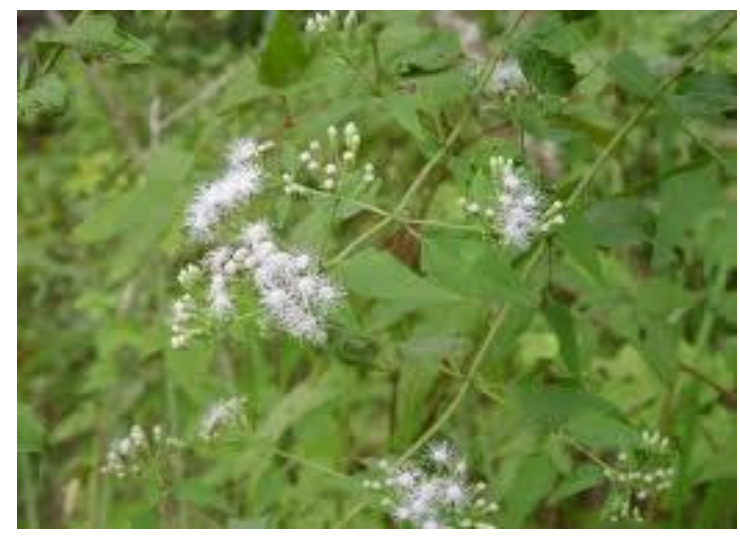

Plate 2: Leaves and flowers of C. odorata

\subsection{EXTRACTION AND FRACTIONATION OF THE LEAF EXTRACTS}

\section{Preparation of Samples}

The fresh leaf samples of Ceratotheca sesamoides and Chromolaena odorata collected from the wild were washed thoroughly with running tap water to remove adhering dirt. Thereafter, the samples were rinsed with distilled water and air dried at room temperature. The dried leaves samples were manually ground into powder using mortar and pestle, sieved, weighed, packaged, and labeled for laboratory analysis.

\section{Extraction of the Plant Samples}

About $300 \mathrm{~g}$ each of the pulverized leaf samples of Ceratotheca sesamoides and Chromolaena odorata was packed into a thimble and placed inside a soxhlet extractor and extracted with $500 \mathrm{~cm}^{3}$ methanol for $48 \mathrm{~h}$. The resulting extract was then concentrated using a rotary evaporator (Büchi Rotavapor, R-205; Quickfit, England) and evaporated to dryness under vacuum.

\section{Partitioning of Extracts}

The crude methanolic extract was fractionated by modified Kupchan partitioning (Beckett and Stenlake, 1986) and Sabrina et al. (2016) method for solvent-solvent partition of crude extracts. The crude extract (35 g) from the mother solution, was partitioned using three solvents of different polarity in a separating funnel (n-hexane, chloroform and ethyl acetate). n-hexane $\left(350 \mathrm{~cm}^{3}\right)$ was added to the crude extract and the funnel was shaken vigorously and then allowed to stand. The organic and aqueous phases were collected separately. This process was repeated three times and all the n-hexane fractions were collected together.

A similar procedure was repeated using chloroform and ethyl acetate, and their respective fractions were separately collected.

The residue fraction was preserved. All the fractions were collected separately and evaporated to dryness using rotary evaporator. Each fraction was subjected separately for phytochemical and antimicrobial analyses. 


\section{Phytochemical Screening of the Extracts}

Phytochemical tests were used for the analysis of reducing sugar, tannins, saponins, cardiac glycosides, steroids, terpenoids ((Trease and Evans, 1983), flavonoids and alkaloids (Sofowora, 1982).

\section{Microbial Test Organisms}

The test organisms used for this study were Klebsiella spp., Pseudomonas aeruginosa, Staphylococcus aureus, Escherichia coli, and Candida albicans. Their clinical isolates were obtained from the Innovative Biotechnology Limited, Keffi and were maintained at $4^{\circ} \mathrm{C}$ in the refrigerator before use.

\section{Bacterial Cultures Used}

The bacteria and fungi cultures used in this study were obtained from the Innovative Biotechnology Limited, Keffi in Nasarawa State.

\section{Antimicrobial Susceptibility Tests}

The antimicrobial activity of the extracts against tested organisms using cup-plate agar diffusion method (Nair and Chanda, 2008). The Mueller Hinton agar (MHA) and Sabouraud dextrose agar (SDA) were prepared, poured into petri dishes, allowed to solidify and labeled properly. Sterile cork borer (6 mm) was used; four holes were bored on the surface of the agar medium equidistant from one another and the base was sealed with sterile melted MuellerHinton agar $0.1 \mathrm{~cm}^{3}$ of various concentrations of the extract $50 \mathrm{mg}, 25 \mathrm{mg}, 12.5 \mathrm{mg}, 6.25 \mathrm{mg}, 3.125 \mathrm{mg}, 1.5 \mathrm{mg}$, and $0.75 \mathrm{mg}$ were dispersed into the wells bore on MHA plates and SDA plates sealed with $10 \mathrm{CFU}$ of test bacteria and $C$. albicans isolate. The MHA plates for test bacterial isolates were incubated at $37^{\circ} \mathrm{C}$ for $24 \mathrm{~h}$ whereas SDA plates for $C$. albicans were incubated at $37^{\circ} \mathrm{C}$ for $72 \mathrm{~h}$. The extent of the radial growth was observed after incubation. The resulting zones of inhibition were measured with a millimeter ruler, surrounding bacterial growth. The experiment was conducted in duplicate.

\section{Determination of Minimum Inhibitory Concentration (MIC)}

The minimum inhibitory concentrations (MICs) of solvent extract against test bacteria and fungi isolates were determined using agar diffusion method. The Mueller-Hinton agar (MHA) and Sabouraud dextrose agar plates containing different concentration of each extract $\left(50 \mathrm{mg} / \mathrm{cm}^{3}, 25 \mathrm{mg} / \mathrm{cm}^{3}, 12.5 \mathrm{mg} / \mathrm{cm}^{3}, 6.25 \mathrm{mg} / \mathrm{cm}^{3}, 3.125\right.$ $\mathrm{mg} / \mathrm{cm}^{3}, 1.56 \mathrm{mg} / \mathrm{cm}^{3}, 0.75 \mathrm{mg} / \mathrm{cm}^{3}$ ) were prepared. $10 \mu \mathrm{l}$ of the standardized test bacteria and fungi isolates were spotted on the surface of MHA plates and SDA plates, the plates were incubated at $37^{\circ} \mathrm{C}$ for $24 \mathrm{~h}$ for bacteria and 72 $\mathrm{h}$ for $C$. albicans. The minimum concentration of the extract that inhibits visible growth was recorded as the MIC.

\section{Determination of Minimum Bactericidal Concentration (MBC)}

The minimum bactericidal concentration (MBC) and minimum fungicidal concentration (MFC) were determined using macro-broth dilution method. Different concentrations of solvent extracts were prepared using Mueller-Hinton and Sabouraud dextrose broth and $10 \mu \mathrm{l}$ of standardized test bacteria was each inoculated into the $5 \mathrm{~cm}^{3}$ tubes and shaken vigorously, and the tubes were incubated at $37^{\circ} \mathrm{C}$ for $24 \mathrm{~h}$ for bacteria isolates and $72 \mathrm{~h}$ for fungi isolates. $10 \mu \mathrm{l}$ from each test tube were spotted on extract free MHA plates and SDA plates and incubated at $37^{\circ} \mathrm{C}$ for $24 \mathrm{~h}$ for bacterial isolates and $72 \mathrm{~h}$ for $C$. albicans. The minimum concentration of the extracts that stop the growth of bacteria and $C$. albicans was recorded as the MBC.

\section{RESULTS AND DISCUSSION}

The results of the phytochemical analysis of the crude methanolic extract of Cerathoteca sesamoides (Table 1) revealed the presence of flavonoids in ethyl acetate, methanolic and residue extracts but absent in n-hexane and chloroform extracts. Saponins are present in chloroform, methanolic and residue extracts but absent in ethyl acetate and n-hexane extracts.

Table 1: Phytochemical Constituents of Cerathoteca sesamoides Leaf Extracts in Various Solvents

\begin{tabular}{|l|l|l|l|l|r|r|}
\hline \multicolumn{5}{|c|}{ Solvents } \\
\hline S/N & Phytochemicals & n-hexane & Chloroform & Ethyl acetate & Methanol & Residue \\
\hline
\end{tabular}


Abubakar M. A., Etonihu A. C., Kigbu P. E., Owuna J. E., and Audu S. I.

\begin{tabular}{|l|c|c|c|c|c|c|}
\hline 1 & Flavonoids & - & - & + & + & + \\
\hline 2 & Saponins & - & + & - & + & + \\
\hline 3 & Cardiac glycosides & + & + & + & + & + \\
\hline 4 & Steroids & + & + & + & + & + \\
\hline 5 & Terpenoides & + & + & + & + & + \\
\hline 6 & Tannins & + & + & + & + & + \\
\hline 7 & Alkaloids & - & - & + & + & + \\
\hline 8 & Anthraquinones & - & - & - & - & - \\
\hline 9 & Reducing sugar & - & - & - & - & - \\
\hline
\end{tabular}

$+=$ Present; $-=$ Absent

Interestingly, the World Health Organization estimates that about $80 \%$ of the population living in Africa use traditional medicine for their primary health care. In addition, of the 300,000 plant species identified to be used in part or in whole for medicinal purposes, it is estimated that only $15 \%$ of them were studied to phytochemical level, 6\% for their actual biological activities (Bothon et al., 2014). The medicinal values of these plants lie in their component phytochemicals, which produce the definite physiological actions on human body. The most important of these phytochemicals are alkaloids, tannins, flavonoids and phenolic compounds (Iwu, 2000). Tannins are present in n-hexane, chloroform, ethyl acetate, methanolic and residue extracts. Alkanoids are present in ethyl acetate, methanolic and residue extracts but absent in n-hexane and chloroform extracts. Steroids, terpenoids, tannins and cardiac glycosides are present in n-hexane, chloroform, ethyl acetate, methanolic and residue extracts. Alkanoids are present in ethyl acetate, methanolic and residue extracts but absent in n-hexane and chloroform extracts.

Thus, in the $C$. odorata sample, flavonoids, cardiac glycosides, steroids, terpenoids were present in all solvent extracts (Table 2). Tannins and alkaloids were present in all solvent extracts except $n$-hexane, while saponins were present in ethyl acetate, methanolic and residue extracts but absent in n-hexane and chloroform extracts. Anthraquinone and reducing sugars were absent in all extracts of Chromoleana odorata samples.

Table 2: Phytochemical Constituents of Chromolaena odorata Leaf Extracts in Various Solvents

\begin{tabular}{|c|c|c|c|c|c|c|}
\hline \multicolumn{9}{|c|}{ S/N } & Phytochemicals & n-hexane & Chloroform & Ethyl acetate & Methanol & Residue \\
\hline 1 & Flavonoids & + & + & + & + & + \\
\hline 2 & Saponins & - & - & + & + & + \\
\hline 3 & Cardiac glycosides & + & + & + & + & + \\
\hline 4 & Steroids & + & + & + & + & + \\
\hline 5 & Terpenoides & + & + & + & + & + \\
\hline 6 & Tannins & - & + & + & + & + \\
\hline 7 & Alkaloids & - & + & + & + & + \\
\hline 8 & Anthraquinones & - & - & - & - & - \\
\hline 9 & Reducing sugar & - & - & - & - & - \\
\hline
\end{tabular}

$+=$ Present; $-=$ Absent

The results of the phytochemical analysis of the partition extracts of both $C$. sesamoides and C. odorata (Table 1 and Table.2) showed the varying proportions of the phytochemicals in the polarity of the solvents used; the polar bioactive constituents being extracted by the polar extracting solvents. C. odorata from Asia is a rich source of flavonoids (Pisutthanan et al., 2006), but the bioactivity of these extracts has been little investigated. Flavonoids from flowers of $C$. odorata from Thailand, from which eight flavonoids were isolated and found to show weak to moderate anti-mycobacterial activity (Suksamrarn et al., 2004). Environmental influences could lead to distinct phytochemical characteristics. Toyin et al. (2012) reported the presence of steroids, triterpenes, alkaloids, flavonoids, tannins, saponins, and glycosides in C. sesamoides. The presence of alkaloids, flavonoids and saponins in these plants is an indication that the plants can be used to cure dysentery and diarrhea as reported by Toyin $e t$ al. (2012).

Terpenes have anti-inflammatory properties, and have been reported to show excellent inhibition of soya lipoxygenase L-1 in C. odorata (Owoyele et al., 2005; Bamba et al., 1993; Bedi et al., 2004). Some of these bioactive 
compounds have been associated with antibacterial activities (Nweze and Okafor, 2007), and may be identified for the medicinal activities of $C$. sesamoides and $C$. odorata. The presence of alkaloids and flavonoids in plant extracts is an indication of anti-inflammatory, antimalarial, and analgesic effects (Okwu and Josiah, 2006) that they could be used to treat malaria, diabetes, cancer, cardiac dysfunction, stomach ache, relief pains, and gastro intestinal disorder. Flavonoids have been reported to have strong activity to change the body's reaction to allergies, virus and carcinogens, as they have anticancer activities, anti-allergic, and anti-inflammatory activities (Okwu, 2004). The presence of saponins suggests that $C$. sesamoides and $C$. odorata may contain useful phytoconstituents that could reduce blood cholesterol level and cancer risk due to its foaming ability that produces frothy effect (Okwu, 2003).

Tannins have been reported to have biological activities that may help in the treatment of many diseases (James et al., 2007), as they prevent the development of microorganisms (Naveen et al., 2008). Generally, tannin-containing plants such as $C$. sesamoides or $C$. odorata can be used to treat diarrhea, inflammations of mouth, sore throat and slightly injured skins (Naveen et al., 2008). The plants can also be used to treat soft wounds, burn wounds and skin infections due to the presence of tannin and it may have astringent property (Osadebe and Ukwueze, 2004). The tannins in these plants may be responsible for their use in traditional medicine for wound healing and local antiseptic agents (Inya-Agha et al., 1987), as the plants decoction are taken as a remedy for coughs and colds or in baths to treat skin diseases (Morton, 1981).

Table 3 and 4 shows the results of antimicrobial susceptibility of methanolic extracts of $C$. sesamoides and $C$. odorata. The results indicated the activity of extracts against all the tested clinical bacteria Klebsiella spp., E. coli, $P$. aeruginosa, $S$. aureus, but inactive against $C$. albicans. The Tables also indicated that $C$. sesamoides was more active than $C$. odorata for the range of concentrations tested. This finding agrees with the report of Gbadamosi and Egunyomi (2010) that the plants successfully inhibited some microbes. However, the report of Ngono et al. (2006) showed that the ethanolic extract of $C$. odorata is active against fungi. The activity of the methanolic extracts against P. aeruginosa (at $12.5 \mathrm{mg} / \mathrm{ml}$ ) in both $C$. sesamoides and $C$. odorata showed that the plants can treat burns, wound swab, soft tissue infection and skin infections. The methanolic extract of these plants showed highest activity against S. aureus (at $6.25 \mathrm{mg} / \mathrm{ml}$ ). This is in agreement with the findings of Bouda et al. (2011), who reported that essential oils from C. odorata exhibit insecticidal and antibacterial activities. Irobi (1997) reported activity of lower concentrations of crude ethanolic extract of leaves of $C$. odorata against $P$. aeruginosa $(8.0 \mathrm{mg} / \mathrm{ml})$, Streptococcus faecalis $(6.0 \mathrm{mg} / \mathrm{ml})$ and S. aureus.

Table 3: Antimicrobial activity of Methanolic extract of Cerathoteca sesamoides

\begin{tabular}{|c|c|c|c|c|c|c|c|c|}
\hline & & \multicolumn{6}{|c|}{ Concentration of Methanolic Extract (mg/ml)/zone of inhibition (mm) } \\
\hline S/N & Test Organism & 50 & 25 & 12.5 & 6.25 & 3.125 & 1.56 & 0.78 \\
\hline 1 & Escherichia coli & $16.0 \pm 0.71$ & $12.0 \pm 2.12$ & 0 & 0 & 0 & 0 & 0 \\
\hline 2 & Klebsiella spp. & $20.0 \pm 0.71$ & $17.0 \pm 2.12$ & $9.0 \pm 2.12$ & 0 & 0 & 0 & 0 \\
\hline 3 & P. aeruginosa & $19.0 \pm 2.82$ & $13.0 \pm 0.71$ & $9.0 \pm 0.71$ & 0 & 0 & 0 & 0 \\
\hline 4 & S. aureus & $24.0 \pm 1.41$ & $19.0 \pm 1.41$ & $16.0 \pm 1.41$ & $11.0 \pm 0.71$ & 0 & 0 & 0 \\
\hline 5 & Candida albicans & 0 & 0 & 0 & 0 & 0 & 0 & 0 \\
\hline
\end{tabular}

Table 4: Antimicrobial activity of Methanolic extract of Chromolaena odorata

\begin{tabular}{|c|c|c|c|c|c|c|c|c|}
\hline & & \multicolumn{6}{|c|}{ Concentration of Methanolic Extract (mg/ml)/zone of inhibition (mm) } \\
\hline S/N & Test Organism & 50 & 25 & 12.5 & 6.25 & 3.125 & 1.56 & 0.78 \\
\hline 1 & Escherichia coli & $23.0 \pm 1.41$ & $18.0 \pm 0.21$ & 0 & 0 & 0 & 0 & 0 \\
\hline 2 & Klebsiella spp. & $22.0 \pm 0.71$ & $17.0 \pm 1.41$ & $9.0 \pm 1.41$ & 0 & 0 & 0 & 0 \\
\hline 3 & P. aeruginosa & $20.0 \pm 1.41$ & $15.0 \pm 0.71$ & $9.0 \pm 1.41$ & 0 & 0 & 0 & 0 \\
\hline 4 & S. aureus & $29.0 \pm 1.41$ & $23.0 \pm 0.71$ & $17.0 \pm 0.71$ & $12.0 \pm 0.71$ & 0 & 0 & 0 \\
\hline 5 & Candida albicans & 0 & 0 & 0 & 0 & 0 & 0 & 0 \\
\hline
\end{tabular}

Table 5 and 6 showed the results of antimicrobial susceptibility of chloroform extracts of $C$. sesamoides and $C$. odorata. The results indicated that the chloroform extracts of both plants had activity against all the tested clinical bacteria Klebsiella spp., E. coli, P. aeruginosa, S. aureus, and C. albicans. 
Abubakar M. A., Etonihu A. C., Kigbu P. E., Owuna J. E., and Audu S. I.

Table 5: Antimicrobial activity of chloroform extract of Cerathoteca sesamoides

\begin{tabular}{|c|c|c|c|c|c|c|c|c|}
\hline & & \multicolumn{6}{|c|}{ Concentration of Chloroform Extract (mg/ml)/zone of inhibition (mm) } \\
\hline S/N & Test Organism & 50 & 25 & 12.5 & 6.25 & 3.125 & 1.56 & 0.78 \\
\hline 1 & Escherichia coli & $20.0 \pm 1.41$ & $14.0 \pm 1.41$ & $12.0 \pm 0.71$ & 0 & 0 & 0 & 0 \\
\hline 2 & Klebsiella spp. & $21.0 \pm 0.71$ & $17.0 \pm 1.41$ & $13.0 \pm 0.71$ & $9.0 \pm 0.71$ & 0 & 0 & 0 \\
\hline 3 & P. aeruginosa & $19.0 \pm 1.41$ & $17.0 \pm 1.41$ & $12.0 \pm 0.71$ & $9.0 \pm 0.71$ & 0 & 0 & 0 \\
\hline 4 & S. aureus & $20.0 \pm 2.82$ & $15.0 \pm 1.41$ & $9.0 \pm 1.41$ & 0 & 0 & 0 & 0 \\
\hline 5 & Candida albicans & $13.0 \pm 0.49$ & $9.0 \pm 5.52$ & 0 & 0 & 0 & 0 & 0 \\
\hline
\end{tabular}

Table 6: Antimicrobial activity of chloroform extract of Chromolaena odorata

\begin{tabular}{|c|c|c|c|c|c|c|c|c|}
\hline & & \multicolumn{6}{|c|}{ Concentration of Chloroform Extract (mg/ml)/zone of inhibition (mm) } \\
\hline S/N & Test Organism & 50 & 25 & 12.5 & 6.25 & 3.125 & 1.56 & 0.78 \\
\hline 1 & Escherichia coli & $23.0 \pm 1.41$ & $18.0 \pm 0.71$ & $10.0 \pm 2.12$ & 0 & 0 & 0 & 0 \\
\hline 2 & Klebsiella spp. & $25.0 \pm 1.41$ & $19.0 \pm 1.41$ & $15.0 \pm 1.41$ & $9.0 \pm 1.41$ & 0 & 0 & 0 \\
\hline 3 & P. aeruginosa & $21.0 \pm 0.71$ & $17.0 \pm 2.82$ & $12.0 \pm 2.82$ & $9.0 \pm 2.12$ & 0 & 0 & 0 \\
\hline 4 & S. aureus & $21.0 \pm 1.41$ & $16.0 \pm 1.90$ & $10.0 \pm 0.00$ & 0 & 0 & 0 & 0 \\
\hline 5 & Candida albicans & $14.0 \pm 0.36$ & $9.0 \pm 2.12$ & 0 & 0 & 0 & 0 & 0 \\
\hline
\end{tabular}

The chloroform extract inhibited the growth of Klebsiella spp. at $21 \mathrm{~mm}$ by $C$. sesamoides and at $25 \mathrm{~mm}$ by $C$. odorata, which indicated the use of these plants in treatment of wound infections, burns, urinary tract infections and chronic liver diseases.

The ethyl acetate extracts of both $C$. sesamoides and $C$. odorata were active against the bacteria Klebsiella spp., E. coli, $P$. aeruginosa, $S$. aureus, and $C$. albicans; but $C$. odorata was more active against the micro-organisms (Table 7 and Table 8). The activity of ethyl acetate extracts (at $12.5 \mathrm{mg} / \mathrm{ml}$ ) against E. coli in both C. sesamoides and C. odorata indicated that the plant leaves can be used to treat infections due to these causative agents, such as urinary tract infections. The activities against $C$. albicans also indicated that the plant extracts could be effective at treating candidiasis.

Table 7: Antimicrobial activity of Ethyl Acetate extract of Cerathoteca sesamoides

\begin{tabular}{|c|c|c|c|c|c|c|c|c|}
\hline & & \multicolumn{6}{c|}{ Concentration of Ethyl acetate Extract $(\mathrm{mg} / \mathrm{ml}) /$ zone of inhibition (mm) } \\
\hline S/N & Test Organism & 50 & 25 & 12.5 & 6.25 & 3.125 & 1.56 & 0.78 \\
\hline 1 & Escherichia coli & $20.0 \pm 0.71$ & $12.0 \pm 2.12$ & $9.0 \pm 0.71$ & 0 & 0 & 0 & 0 \\
\hline 2 & Klebsiella spp. & $17.0 \pm 0.71$ & $10.0 \pm 0.71$ & 0 & 0 & 0 & 0 & 0 \\
\hline 3 & P. aeruginosa & $16.0 \pm 1.41$ & $9.0 \pm 2.12$ & 0 & 0 & 0 & 0 & 0 \\
\hline 4 & S. aureus & $18.0 \pm 2.82$ & $13.0 \pm 1.41$ & $8.0 \pm 1.41$ & 0 & 0 & 0 & 0 \\
\hline 5 & Candida albicans & $19.0 \pm 0.71$ & $12.0 \pm 0.71$ & 0 & 0 & 0 & 0 & 0 \\
\hline
\end{tabular}

Table 8: Antimicrobial activity of Ethyl Acetate extract of Chromolaena odorata

\begin{tabular}{|c|c|c|c|c|c|c|c|c|}
\hline & & \multicolumn{6}{|c|}{ Concentration of Ethyl acetate Extract (mg/ml)/zone of inhibition (mm) } \\
\hline S/N & Test Organism & 50 & 25 & 12.5 & 6.25 & 3.125 & 1.56 & 0.78 \\
\hline 1 & Escherichia coli & $22.0 \pm 0.71$ & $15.0 \pm 0.71$ & $9.0 \pm 1.141$ & 0 & 0 & 0 & 0 \\
\hline 2 & Klebsiella spp. & $19.0 \pm 0.71$ & $12.0 \pm 0.71$ & 0 & 0 & 0 & 0 & 0 \\
\hline 3 & P. aeruginosa & $16.0 \pm 0.71$ & $9.0 \pm 0.71$ & 0 & 0 & 0 & 0 & 0 \\
\hline 4 & S. aureus & $18.0 \pm 0.71$ & $13.0 \pm 0.71$ & $9.0 \pm 0.70$ & 0 & 0 & 0 & 0 \\
\hline 5 & Candida albicans & $17.0 \pm 1.41$ & $11.0 \pm 0.47$ & 0 & 0 & 0 & 0 & 0 \\
\hline
\end{tabular}

The minimum inhibition concentration (MIC) is the lowest concentration of an antibacterial agent necessary to inhibit visible growth or bacteriostatic. MICs are used to evaluate the antimicrobial efficacy of various compounds by measuring the effect of decreasing concentrations of antibiotic/antiseptic over a defined period in terms of inhibition of microbial population growth. These evaluations can be quite useful during the R\&D phase of a product to determine appropriate concentrations required in the final product, as the concentration of drug required to 
produce the effect is normally several hundred to thousands of times less than the concentration found in the finished dosage form. The minimum inhibitory concentration of the extracts was determined to ascertain the potency of the extracts against the test organisms at different concentrations in which the growth of all the test organisms were inhibited at concentration of $50 \mathrm{mg} / \mathrm{ml}, 25 \mathrm{mg} / \mathrm{ml}, 12.5 \mathrm{mg} / \mathrm{ml}$ and $6.5 \mathrm{mg} / \mathrm{ml}$ with the exception of Candida albicans which shows only growth at the concentrations of $50 \mathrm{mg} / \mathrm{ml}$ and $25 \mathrm{mg} / \mathrm{ml}$ in a chloroform solvent extracts as shown in Tables 3, 4, 5, 6, 7, 8 and 10.

The minimum bactericidal concentration (MBC) is the lowest concentration of an antibacterial agent required to kill $\geq 99.9 \%$ of a particular bacterium (or, bacteriocidal). In this present study, the lowest MBC for Cerethoteca sesamoides and Chloromolaena odorata was observed for E. coli, Klebsiella spp. and Pseudomonas aeruginosa at concentration of $50.0 \mathrm{mg} / \mathrm{ml}$ each respectively from chloroform extracts. However, a $50 \mathrm{mg} / \mathrm{ml} \mathrm{MBC} \mathrm{was} \mathrm{recorded}$ for Staphylococcus aureus for the methanolic extracts of these plants as presented in Table 9. Tables 9 and 10 showed that while the MIC ranged between $12.5 \mathrm{mg}$ and $>50 \mathrm{mg}$, the MBC ranged between $50 \mathrm{mg}$ and $>50 \mathrm{mg}$. Tripathi (2013) reported that the closer the MIC is to the MBC, the more bactericidal the compound or extract.

Table 9: Minimum bactericidal concentration $(\mathrm{mg} / \mathrm{ml})$ of extracts against bacteria and fungi isolates for Cerathoteca sesamoides and Chromolaena odorata

\begin{tabular}{|c|c|c|c|c|c|}
\hline & E. coli & Klebsiella Spp & P. aeruginosa & S. aureus & C. albicans \\
\hline Solvent Extracts & C.S C.O & C.S C.O & C.S C.O & C.S C.O & $\begin{array}{ll}\text { C.S } & \text { C.O }\end{array}$ \\
\hline Chloroform & $50.0 \quad 50.0$ & 50.0 & $50.0 \quad 50.0$ & $50.0 \geq 50.0$ & $\geq 50.0 \geq 50.0$ \\
\hline Ethyl acetate & $50.0 \geq 50.0$ & $50.0 \geq 50.0$ & $50.0 \geq 50.0$ & $50.0 \geq 50.0$ & $50.0 \geq 50.0$ \\
\hline Methanolic & $\geq 50.0 \geq 50.0$ & $50.0 \geq 50.0$ & $50.0 \geq 50.0$ & $50.0 \quad 50.0$ & $\geq 50.0$ \\
\hline
\end{tabular}

C.S = Cerathoteca sesamoides $;$ C.O = Chromolaena odorata

Table 10: Minimum inhibitory concentration $(\mathrm{mg} / \mathrm{ml})$ of extracts against bacteria and fungi isolates for Cerathoteca sesamoides and Chromolaena odorata

\begin{tabular}{|c|c|c|c|c|c|}
\hline & E. coli & Klebsiella Spp & P. aeruginosa & S. aureus & C. albicans \\
\hline Solvent Extracts & C.S C.O & C.S C.O & C.S C.O & C.S C.O & C.S $\quad$ C.O \\
\hline Chloroform & 50.0 & $25.0 \quad 12.5$ & $\begin{array}{ll}50.0 & 50.0 \\
\end{array}$ & $\geq 50.0 \quad 25.0$ & $\geq 50.0 \geq 50.0$ \\
\hline Ethyl acetate & $50.0 \geq 50.0$ & $50.0 \geq 50.0$ & $50.0 \geq 50.0$ & $50.0 \geq 50.0$ & $50.0 \geq 50.0$ \\
\hline Methanolic & $\geq 50.0 \geq 50.0$ & $\geq 50.0 \geq 50.0$ & $\geq 50.0 \geq 50.0$ & $\geq 50.0 \geq 50.0$ & $\geq 50.0$ \\
\hline
\end{tabular}

C.S = Cerathoteca sesamoides $;$ C.O = Chromolaena odorata

\section{CONCLUSION}

The presence of bioactive constituents (including phytochemicals) have made Cerathoteca sesamoides and Chromolaena odorata very useful in traditional medicine. Among the four different solvents used in partitioning methanolic and ethyl acetate extracts of both plants contain flavonoids, tannins, alkaloids, terpenoids, saponins, steroids, and cardiac glycosides. Saponins were absent in the chloroform extract of $C$. odorata and the ethyl acetate extract of $C$. sesamoide. While flavonoids were present in the n-hexane extracts of $C$. odorata, they were absent in $C$. sesamoides. Anthraquinone and reducing sugar were absent in all the solvent extracts of both medicinal plants. This shows that the presence of these bioactive components is related to the type and polarity of the extracting solvents. The antimicrobial susceptibility tests showed that n-hexane and residue extracts of both plants had no activity against the tested microorganisms. The chloroform and ethyl acetate extracts of $C$. sesamoides and $C$. odorata were active against all the tested clinical bacteria $K$. spp., E. coli, $P$. aeruginosa, $S$. aureus, and C. albicans at high concentrations. The methanolic extracts of both plants were active against the bacterial isolates but inactive against the fungus $C$. albicans. The minimum bactericidal concentrations of these plant extracts ranged between $50 \mathrm{mg}$ and $>50 \mathrm{mg}$, while the minimum inhibition concentrations ranged between $12.5 \mathrm{mg}$ and >50 mg. Consequently, the chloroform or ethyl acetate extracts of the leaves of these plant drugs could be used to treat infections due to these causative agents, such as urinary tract infections and candidiasis. 
Abubakar M. A., Etonihu A. C., Kigbu P. E., Owuna J. E., and Audu S. I.

\section{SOURCES OF FUNDING}

This research received no specific grant from any funding agency in the public, commercial, or not-for-profit sectors.

\section{CONFLICT OF INTEREST}

The author have declared that no competing interests exist.

\section{ACKNOWLEDGMENT}

None.

\section{REFERENCES}

[1] Adesiyun AA, Uddin RO (2011). Insects associated with Bungu, Ceratotheca sesamoides in Ilorin, Nigeria. Agricultural and Biological Journal of North America, 2(6): 974-980.

[2] Bamba D, Bessiere J M, Marion C, Pelissier, Y, Fouraste, I (1993). Essential oil of Eupatorium odoratum. Planta Medica 59: 184-185.

[3] Beckett AH, Stenlake JB (1986). Practical Pharmaceutical Chemistry, 3rd Ed. Part 1\&2 CBS Publishers, Delhi.

[4] Bedi G, Tonzibo ZF, Chopard C, Mahy JP, N'guessan TY (2004). Etude des effets antidouleurs des huiles essentielles de Chromolaena odorata et de Mikania cordata, par action sur la lipoxygenase L-1 de soja. Physical Chemistry News 15: 124-127.

[5] Bedigian D, Adetula OA (2004). Ceratotheca sesamoides Endl. Prota 2: Vegetables/Legumes. Wageningen, Netherlands: PROTA.

[6] Bothon FTD, Moustapha M, Sophie Bogninou G, Dossa CPA, Yehouenou B, Medoatinsa SE, Noudogbessi JP, Avlessi F, Sohounhloue DCK (2014). Chemical characterization and biological activities of Newbouldia laevis and Pterocarpus santalinoides leaves. Bulletin of Environmental Pharmacognosy and Life Sciences, 3(11): 915.

[7] Bouda HLA, Tapondjou DA, Fontem T, Gumedzoe MYD (2001). Effect of essential oils from leaves of Ageratum conyzoides, Lantana camara and Chromolaena odorata on the mortality of Sitophiluszeamais (Coleoptera curculionidae). Journal of Stored Products Reserve, 37: 103-109.

[8] Evans WC, Trease E (2002). Pharmacognosy, 15th ed. London. W. B. Saunders Co. Ltd., pp. 191-393.

[9] Falusi OA, Funmi FM, Salako EA (2002). Inheritance of stem and petiole in a selection from local (Nigeria) germplasm of sesame. Tropicultura, 20(3): 156-158.

[10] Fasakin K (2004). Proximate composition of Bungu (Ceratotheca sesamoides) leaves and seeds. Biokemistri, 16(2): $88-92$.

[11] Gbadamosi IT, Egunyomi A (2010). Phytochemical screening and extracts of in vitro anti-candidal activity of essential oil of Curculigo pilosa (Schum and Thonn). Engl. Hypoxidaceae. African Journal of Biotechnology 9(8): 20-26.

[12] Inya-Agha SI, Oguntimein BO, Sofowora A, Benjamin TV (1987). Phytochemical and potential synergy of cancer prevention.

[13] Irobi ON (1997). Antibiotic properties of ethanol extract of Chromolaena odorata Asteraceae. International Journal of Pharmacognosy, 35: 111-115, 127.

[14] Iwu MM (2000). Handbook of Africa medicinal plants. London, UK, CRC Press Inc., p. 19.

[15] James DB, Abu EA, Wurochekk AU, Orji GN (2007). Phytochemical and antimicrobial investigations of aqueous and methanolic extracts of Ximenia americana. Journal of Medical Science, 7(2): 284 -288.

[16] Kamboj VP (2000). Herbal Medicine. Current Science, 78: 35-39.

[17] Morton JF (1981). Atlas of medicinal plants of middle America, Vol. II. Charles C. Thomas, publisher, Springfield, Illinois, USA, pp. 932 - 933.

[18] Mukeshwar P, Mousumi D, Shobit G, Surender KC (2011). Phytomedicine: An ancient approach turning into future potential source of therapeutics. Journal of Pharmacognosy and Phytotherapy, 3(1): 113 -117. 
[19] Nair R, Chanda S (2008). Antibacterial and phytochemical of Punica granatum in different solvents. Indian Journal of Pharmaceutical Science, 67: 239-243.

[20] Naveen PR, Viswanathan S, Renuka DV, Jayashree N, Sweth VC, Archana R, Parathasarathy N, Johanna, R (2008). Preliminary phytochemical screening and antimicrobial activity of Samanea saman. Journal.of Medicinal Plant Research, 2(10): 268-270.

[21] Ngono NA, Ebelle E R, Ndifor F, Biyiti L, Amvam ZPH, Bouchet P (2006). Antifungal activity of Chromolaena odorata (L.)

[22] Nweze EI, Okafor JI (2007). Increasing cases of tinea capitis dermatophytoses in children of school age in Nigeria. 2nd Pan African Medical Mycology Society Conference, Cape Town, South Africa 7, 13-20.

[23] Okwu DE (2003). The potentials of Ocimum gratissimum, Penrgularia extensa and Tetrapleura tetraptera as spice and flavouring agents. Nigerian Agricultural Journal, 34: 143 - 48.

[24] Okwu DE (2004). Phytochemicals and vitamin content of indigenous spices of southeastern Nigeria. Nigerian Journal of Sustainable Agriculture and Environment, 6(1): 30-37.

[25] Okwu DE, Josiah C (2006). Evaluation of the chemical composition of two Nigerian medicinal plants. African Journal of Biotechnology, 5(4): 357 - 361.

[26] Osadebe PO, Ukwueze SE (2004). A comparative study of the phytochemical and antimicrobial properties of the eastern Nigerian species of African Mistletoe (Loranthus micranthus) sourced from different host area trees. Journal of Biological Resources and Biotechnology, 2(1):18 -23.

[27] Owoyele VB, Adediji JO, Soladoye AO (2005). Anti-inflammatory activity of aqueous leaf extract of Chromolaena odorata. African Journal of Biotechnology, 4(3),135-138.

[28] Phan TT, See P, Lee ST, Chan SY (2001). Anti-oxidant effects of the extracts from the leaves of Chromolaena odorata on human dermal fibroblasts and epidermal keratinocytes against hydrogen peroxide and hypoxanthine-xanthine oxidase induced damage. Burns, 27: 319 - 327.

[29] Pisutthanan N, Liawruangrath B, Liawruangrath S, Bremner JB (2006). A new flavonoid from Chromolaena odorata. Natural Product Research, 20: 1192 - 1198.

[30] Sabrina S, Zahidul MD, AbdulJabber MD (2016). Isolation and identification of medicinal compounds from Kalanchoe pinnata of Crassulaceae family by H-NMR. Journal of Bioscience and Bioengineering Communication, 2(2): 123-129.

[31] Sofowora A (1982). The state of medicinal plant research in Nigeria. London, Royal Botanical Gardens, 3(5): 56-71.

[32] Stella FA, Enthoven RE, Kingscote H, Sastri PN, Dey LB, Tawney CH, Anthon RR, Neogi SN, Oakley ES, Gairola ES, Edgerton F (2000). Encyclopaedia of Indian folk literature, vol. 11. Cosmo Pub.

[33] Suksamram A, Chotipong A, Suavansri T (2004). Antimycobacterial activity and cytotoxicity of flavonoids from the flowers of Chromolaena odorata. Archeaological and Pharmaceutical Research, 27: 507-511.

[34] Toyin YM, Khadijat OF, Saoban SS, Olakune AT, Abraham BF, Luqman QA (2012). Antidiarrheal activity of the aqueous leaf extract of Ceratotheca sesamoides in rats. Bangladesh Journal of Pharmacology, 7(1): $14-20$.

[35] Trease E, Evans, WC (1983). Pharmarcognosy, vol. 3. London, Bailliere Indall, pp. 21-22.

[36] Tripathi, K.D (2013). Essentials of Medical Pharmacology, 7th ed.. New Delhi, India: Jaypee Brothers Medical Publishers. pp. 696, 697.

[37] World Health Organization (WHO, 2000). General guidelines for methodologies on the research and evaluation of traditional medicines, Vol. 8. Geneva, World Health Organization, pp. 235 -239.

[38] World Health Organization (WHO, 2005). Post-harvest and pressing technology of staple food. Technical Compendium of WHO Agricultural Science Bulletin, Vol. 88. Geneva, World Health Organization, pp. 171-172. 